\title{
A rare case of retained fourth molar teeth in maxilla and mandible. Case report
}

\author{
Mansur Rahnama, Anna Szyszkowska, Marta Pulawska*, Joanna Szczerba-Gwozdz
}

The Chair and Department of Oral Surgery, Medical University of Lublin, 7 Karmelicka Str., 20-081 Lublin, Poland

\section{ARTICLE INFO}

Received 07 July 2014

Accepted 14 July 2014

\section{Keywords:}

fourth molar,

impacted tooth,

oral surgery,

wisdom teeth,

supernumerary teeth.

\begin{abstract}
The study presents a case of the rarely occurring totally retained fourth molar teeth simultaneously in maxilla and mandible. The appearance of supernumerary teeth is a relatively uncommon dental anomaly and it is rare for patients to have impacted fourth molars in two quadrant. The aim of this work is to describe the presence of unilateral (right) fourth molars in the maxilla and the mandible in a young female patient aged 24 years. Orthopantomogram revealed impacted lower third molars but also unerupted unilateral (right) upper and lower fourth molars. Before orthodontic treatment, the patient was subsequently admitted for removal of third and fourth impacted upper and lower molars under local anesthesia.
\end{abstract}

\section{INTRODUCTION}

A distomolar (dens distomolar) is a supernumerary tooth that is located distally to a wisdom tooth and when fully erupted extends the dental arch [5]. Such a tooth is called a fourth molar. A supernumerary molar sometimes occurs as a tooth coalesced with a wisdom tooth or its additional cusp in its residual form. A distomolar can have a normal anatomical structure characteristic of this set of teeth with a fully-formed crown, single root, and be clearly separated from the adjacent teeth or it can diverge in its shape from a regular molar. A distomolar as a residual tooth often remains in its early stage of development. Fourth molars can fully erupt and be in alignment in the dental arch or they can undergo partial eruption or impaction. As the eruptive force of the tooth is not great it does not cause any disorders within the dental arch remaining at the same time undiscovered until a routine radiological examination. On radiographs, distomolars can be seen as clear osteosclerotic foci. A ratio of erupted distomolars to impacted ones is 1 to 5 . According to the literature, the incidence of supernumerary teeth in population is estimated to be $0,2-0.3 \%[1,5,9]$.

Etiopathogenesis of this anomaly has not been resolved yet. In the literature, one can find various theories of

\footnotetext{
Corresponding author

e-mail: pulawska.marta@wp.pl

tel.: +48 81 528-79-50,

fax: +48 81 528-79-51
}

hyperdontia, namely atavistic, vascular, genetic (hereditary) and hyperdontia of dental lamina hyperfunction.

An atavistic theory holds that the occurrence of supernumerary teeth is the return to the teeth pattern of primitive higher mammals/eutheria with dental formula 3143 and having 44 teeth. It should be noticed though that the primitive dental formula includes neither supernumerary canine nor distomolars - retromolars.

A vascular theory explains the occurrence of supernumerary teeth in the front part of the maxilla. The authors of this theory assume that such a location is related to the survival of a sphenopalatine artery that should have disappeared along with embryonic development of a specimen.

According to a genetic theory, supernumerary teeth result from activation of genetic information that was deactivated in the process of evolution. The occurrence of atavistic forms in humans indicates that genetic information, contained in DNA, may be latent across many generations and is activated by the organism in specific and favourable circumstances.

An inheritance theory says about familial occurrence of hyperdontia. Such a thesis is a subject of many suggestions that assume autosomal dominant inheritance and autosomal recessive inheritance either X-linked or polygenic. A view on inheritance connected with sex was proved by observations of many authors who noticed more frequent occurrence of hyperdontia in boys.

The concept of hyperfunction of dental lamina assumes that after a normal number of teeth buds supernumerary teeth appear. Dental lamina that did not undergo the process 
of resorption causes the extended in time ability to produce new teeth. The local factors such as inflammatory processes, scariing, pressure and injuries may be the causes of dental lamina hyperfunction $[1,8,9,11,12]$.

Supernumerary teeth depending on their location are defined as mesiodens, paramolars and distomolars. In daily dental practice, supernumerary distomolars are the least frequently to encounter.

Distomolars may be the cause of odontogenic inflammation, primordial or odontogenic cysts, periodontal diseases and neuralgic pains.

\section{CASE REPORT}

A 24-year-old female patient was referred by an orthodontist to The Chair and Department of Oral Surgery in Lublin for extraction of teeth 18, 19, 28, 38, 48, 49 before the planned orthodontic treatment. The patient's medical history contained no information about systemic diseases or familial incidence of supernumerary teeth. An intra-oral examination showed presence of erupted teeth 18, 28 and partially erupted tooth 38 .

An orthopantomogram in turn presented impacted teeth 19, 48, 49 (Fig. 1). The maxillary distomolar was unerupted, in a vertical position distal to the third molar. The mandibular distomolar was unerupted, in a horizontal position distal to the third molar. They were smaller than the regular molars. The patient was qualified for teeth extraction surgeries to be performed at adequate intervals.

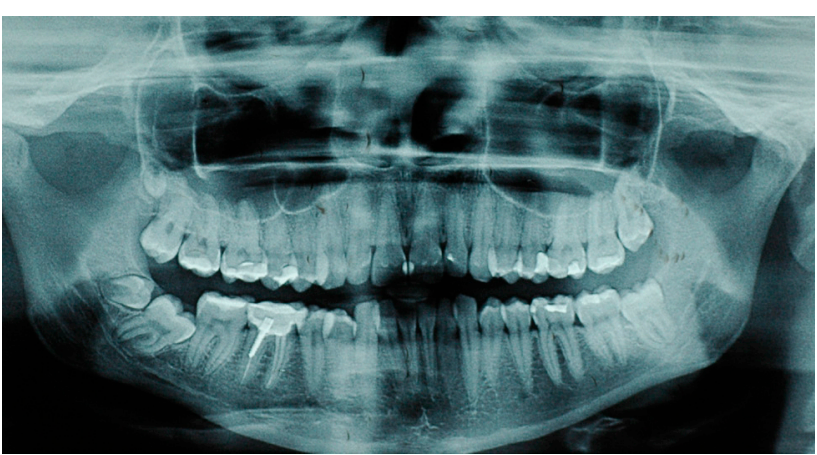

Figure 1. Orthopantomogram showing impacted lower third molar but also totally retained upper and lower fourth molars on the right side of the patient

The tooth 28 was removed by simple extraction while the remaining teeth $18,19,38,48,49$ needed a surgery extractions with a cut and detachment of mucoperiosteal flap.

The upper fourth molar 19 was removed in a one-stage procedure together with the upper third molar 18. The extraction of the teeth 48 and 49 was performed in two stages starting with the removal of the tooth 48 . After the period of six months the tooth 48 was extracted. All postoperative lesions were closed with the use of interrupted stitches Safil 3.0.

There were no complications during and after the surgery. The stitches were taken out after 7 days. The supernumerary teeth 19 and 49 were much smaller than the normal teeth 18 , 48. The tooth 19 had the crown with one cone-shaped cusp and a single root with a malformed apex (Fig. 2). After the distomolar 49 had been removed a crown with three cusps and a single root with unclosed apex was found (Fig. 3).

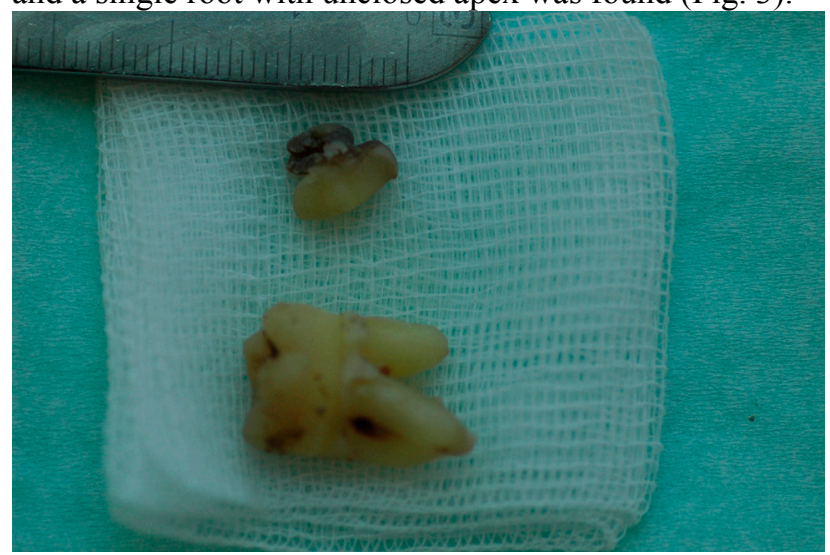

Figure 2. The removed upper third and fourth molars (18 and 19)

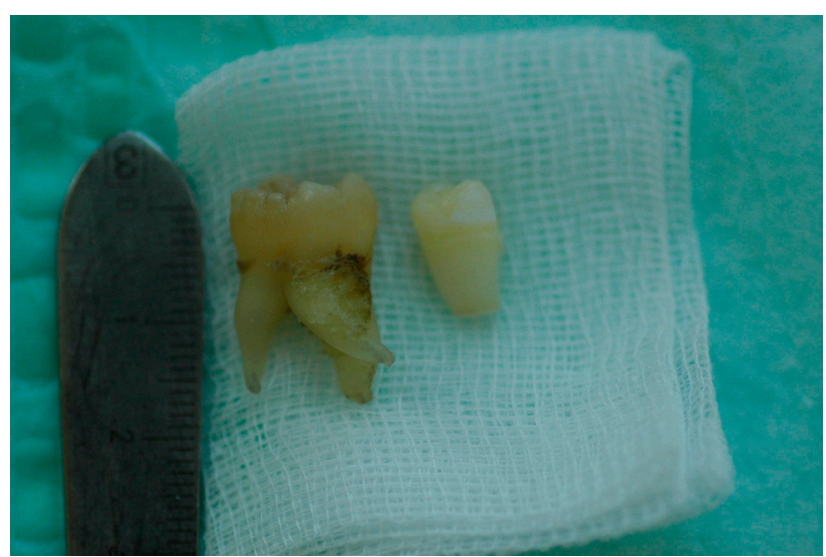

Figure 3. The removed lower third and fourth molars (48 and 49)

\section{DISCUSSION}

Supernumerary teeth may be found in both the primary and permanent dentition, although they are more common in the permanent dentition. Supernumerary molars are divided into two types, depending on their location: distomolars and paramolars. Distomolars are supernumerary teeth that are distal to the third molars, while paramolars are supernumerary teeth on the side of the molars. Presence of a fourth molar is rare, and such a tooth is almost invariably impacted. Dental practitioners should be aware of the possibility of encountering this rare supernumerary, its diagnosis and treatment [4].

The indications for the surgical distomolars extraction are inflammatory complications and chronic pains [3, 12]. The surgeries may be performed due to orthodontic reasons as well. While planning a distomolars extraction a list of features should be taken under consideration, namely their location and access to the teeth during the surgery, potential problems with their removal and a possibility of complications that may occur during or after the surgery.

Fourth molars are often discovered by chance during the radiologic diagnostics and cause no complications. Because impacted distomolars display no clinical signs there is no need for their extraction as s preventive measure. The recommended procedure is to keep such teeth under observation and systematic radiological control. 
Cases of four distomolars with normal morphology are extremely rare and have seldom been reported in the dental literature. The supernumerary teeth may have normal tooth morphology with regard to their crowns and roots but are slightly smaller than the existing third molars. Their crowns may be either two or three tuberculated and they may have single roots [6].

Supernumerary teeth have frequently been observed as solitary teeth and impacted in the maxillary arch. A distomolar occurs more frequently in the maxilla [6,7]. A small number of authors describe single cases of fourth molars incidence in the mandible $[5,12]$.

Fourth molars occur very rarely in the maxilla and the mandible simultaneously.

The phenomenon is interesting especially considering the fact that in contemporary humans, missing third molars are becoming a common finding $[2,10]$.

\section{REFERENCES}

1. Białkowska-Głowacka J. et al.: Rzadkie przypadki występowania zębów trzonowych czwartych w szczęce. Mag. Stomatol., 12, 3, 34-35, 2002.
2. Clementini M. et al.: Four impacted fourth molars in a young patient: a case report. Oral Implantol. (Rome), 5, 4, 100-103, 2013.

3. Dojs M., Roicka A.: Przydatność zdjęć pantomograficznych do oceny położenia zębów przytrzonowych i zatrzonowych. Opis przypadków. Ann. Acad. Med. Stetin., 53, 1, 83-85, 2007.

4. Harel-Raviv M. et al.: Fourth molars: a clinical study. Dent. Update, 23, 9, 379-382, 1996.

5. Janas A.: Całkowicie zatrzymany czwarty ząb trzonowy u 21-letniej pacjentki. Dent. Forum, 37, 2, 89-91, 2009.

6. Kokten G., Balcioglu H., Buyukertan M.: Supernumerary fourth and fifth molars: a report of two cases. J. Contemp. Dent. Pract., 4, 4, 67-76, 2003.

7. Koo S. et al.: Bilateral maxillary fourth molars and a supernumerary tooth in maxillary canine region - a case report. SADJ., 57, 10, 404-406, 2002.

8. Lewandowski B., Lech M.: Zatrzonowcowe zęby zatrzymane przyczyną zębopochodnych okołowierzchołkowych stanów zapalnych. Stomatol. Współcz., 13, 2, 26-30, 2006.

9. Rosak P. et al.: Dziewiątki - atawizm zębowy? Twój Prz. Stomatol., 3, 60-63, 2008.

10. Shultsman M., Taicher S.: Fourth molars in the maxilla and mandible - a rare phenomenon. Refuat. Hapeh. Vehashinayim., 20, 2, 35-37, 2003.

11. Zadurska M. et al.: Nadliczbowość zębów - na podstawie piśmiennictwa. Czas. Stomat., 58, 4, 265-272, 2005.

12. Zappa J., Cieślik T.: Zatrzymane czwarte zęby trzonowe w żuchwie i szczęce - opis przypadku. Dent. Forum, 34, 1, 91-94, 2006. 